\title{
THE INFLUENCE OF OLANZAPINE AND ARIPIPRAZOLE ON SPATIAL MEMORY OF FEMALE RATS EXPOSED TO STRESS IN PERINATAL PERIOD
}

\author{
KRZYSZTOF KUS*, PIOTR RATAJCZAK, TOMASZ ZAPRUTKO, \\ DOROTA KOPCIUCH, ANNA PACZKOWSKA and ELŻBIETA NOWAKOWSKA
}

Department of Pharmacoeconomics and Social Pharmacy, Poznan University of Medical Sciences, Rokietnicka 7, 60-806 Poznań, Poland

\begin{abstract}
Cognitive functions, such as learning and memory, are instrumental in improving the patient's quality of life. Commonly used antipsychotic drugs are also useful in depression treatment and have a positive effect on spatial memory dysfunction caused by schizophrenia. Olanzapine (OLA) and aripiprazole (ARI) are known to have substantially different pharmacokinetics depending on sex, thus their therapeutic efficacy and dose of treatment may be different for males and females. The aim of the study was to assess whether dysfunction of spatial memory (Morris Water Maze - MWM) and locomotor activity (LA) improve in prenatally stressed rats (animal model of schizophrenia (AMS)) by OLA and ARI. OLA $(0.5 \mathrm{mg} / \mathrm{kg}$ ip) and ARI ( $1.5 \mathrm{mg} / \mathrm{kg}$ ip) were administered to female Wistar rats (non-stressed control group (NSCG) and PSG). Single administration of ARI and OLA in the NSCG yielded no differences in spatial memory compared to the control group (C-NSCG), while OLA improved memory after 7 days of treatment compared to the C-NSCG. In the prenatally stressed group (PSG), an impairment of spatial memory by the drug was observed (vs. C-NSCG) after long-term treatment. Only chronic administration of ARI and OLA (PSG) improved spatial memory in female rats. Stress causes memory dysfunction in female rats. Chronic administration of ARI and OLA reverses this effect which can probably be associated with the mechanism of action of the drugs used (ARI/OLA). ARI acts as an agonist or antagonist mainly on D2 and 5-HT2A receptors, while OLA induces antagonist effects for these receptors.
\end{abstract}

Keywords: aripiprazole, olanzapine, female rats, prenatal stress, variation in sexes

The prevalence of schizophrenia is $1 \%$ worldwide with both positive and negative symptoms constituting the clinical image of the disease $(1,2)$. Schizophrenia is defined as acute psychosis characterized by auditory hallucinations, delusions, interferences of cognition, and uncontrolled demeanors. In most cases, the disease starts early in human life and, as it progresses, interpersonal, social and professional functioning of the patient deteriorates $(3,4)$.

The study conducted by Holzman (5) indicated that the development of schizophrenia is determined mainly by genetic factors, family relationships being less important. Nowadays, it is widely accepted that the genetic propensity to suffer from schizophrenia is a polygenic phenomenon and the occurrence of the disease might be related to the effect of harmful environmental factors $(6,7)$.

The incidence of schizophrenia is higher among men than women. It has been pointed out that perinatal brain damages have an impact on the development of neurons and functioning of the Central Nervous System (CNS), which can increase the probability of developing mental disorders. It has been observed that, in people suffering from schizophrenia, the number of neurons decreases and neuronal connections, as well as brain structures, may be disturbed (cerebral cortex, hippocampus, cerebellum, thalamus). Moreover, disturbances in neurotransmission within the CNS induce functional deficits and increase susceptibility to stress $(8,9)$ which enhances the occurrence of schizophrenia. Stress activates the release of cortisol in humans and corticosterone in animals $(10,11)$ as well as monoamine transmission in the CNS. According to animal studies $(12,13)$ in which prenatal stress was being induced, there are significant changes e.g. in the neuroendocrine system of newborn offspring, or the animals' locomotor activity is reduced. Spatial memory impairment has also been noted in these

\footnotetext{
* Corresponding author: e-mail: kkus@ump.edu.pl
} 
animals during the Morris Water Maze (MWM) test $(11,14)$.

Aripiprazole (ARI) is a partial agonist of 5HT1A and dopamine (DA), an antagonist of 5HT2A receptors $(1,15)$ with an affinity to adrenergic $\alpha 1$ and histamine $\mathrm{H} 1$ receptors $(16,17)$.

The antipsychotic activity of olanzapine (OLA) depends on the antagonistic effect of the drug on D2 and 5-HT2A receptors in the frontal cortex. It has been observed that antagonism to D2 receptors decrease positive symptoms of schizophrenia, while antagonism to 5-HT2A or D3 receptors decrease negative symptoms of the disease $(18,19)$. Assumingly, the ability to activate the c-fos factor in the prefrontal cortex is responsible for OLA's antipsychotic activity which may be associated with the drug's effect of on negative symptoms of schizophrenia (20).

The terapeutic effect of drugs depends on pharmacokinetic parameters (LADME) which depend on the patients' age and gender or dose of the drug applied (21). During the absorption stage, differences in the release of the drug substance caused by smaller secretion of gastric acid in women due to the predominance of the alkaline environment have been observed. This may possibly lead to slower absorption and decreased $\mathrm{C}_{\max }(22)$. This effect is always lower in women, regardless of the estrous cycle. Women also display a decreased first-pass effect that is caused by increased expression of CYP2D6 isoenzyme (22-24). In men, however, lesser vulnerability to some drugs has been noted. It depends on faster biotransformation, which can be explained by the influence of testosterone on the induction of microsomal enzyme activity in the liver (24). Several research studies indicate that the membrane transport protein, p-glycoprotein, is responsible for differences in drug metabolism. The expression of this protein in the liver is strongly connected with CYP3A and is higher in men than in women (25).

Considering gender differences, which are relevant for the therapeutic effect of drugs applied, and our own studies $(11,26)$ indicating improvement of memory after administration of ARI and OLA to (male) animals with behavioral functions (including spatial memory) disturbed by prenatal stress, it was important to establish the impact of prenatal stress on memory functions of newborn females and observing whether ARI and OLA modify these functions.

\section{MATERIALS AND METHODS}

\section{Animals}

Timed pregnant Wistar female rats (30) were purchased from Poznan University of Medical
Sciences, Poland; (licensed by the Ministry of Agriculture in Warszaw, Poland) and arrived at our animal facility on day 2 of gestation. The pregnant animals were housed individually in a light-controlled (lights on 07.00-19.00 h) and temperature and humidity-controlled animal facility. The dams had free access to rat chow (Labofeed B) and water. For tests, female rats born to mothers subject to prenatal stress during pregnancy were used.

The total number of animals taken in the study was 130 (30 mothers, 50 female offspring, 50 control group of females). Adolescent female rats (100 animals - 60-70 days after birth) were divided into two groups - Non-Stressed Control Group (NSCG) - (50 rats - non-prenatally stressed females) and Prenatally Stressed Group (PSG) - (50 rats - prenatally stressed offspring of the 30 stressed females). Animals were selected from different litters (different mothers) and were subsequently randomly distributed into experimental groups: locomotor activity (LA) (40) and MWM (60).

All procedures related to the use of rats in these experiments were conducted with due respect to ethical principles regarding experiments on animals (Local Ethical Commission for Research on Animals).

\section{Drugs}

Carboxymethylcellulose sodium (CMC) was obtained from Koch-Light Laboratories (London, England), ARI from Otsuka Pharmaceutical Europe, Bristol-Myers Squibb Poland, OLA from Eli Lilly Poland and apomorphine (APO) from Sigma Aldrich Poland.

The female rats were administered ARI (1.5 $\mathrm{mg} / \mathrm{kg})$, OLA $(0.5 \mathrm{mg} / \mathrm{kg})$ or the vehicle intraperitoneally (ip) $30 \mathrm{~min}$ before the test and for 7, 14 and 21 days. APO $(2.0 \mathrm{mg} / \mathrm{kg})$ was administered subcutaneously $(s c)$ only once $20 \mathrm{~min}$ before the test. ARI and OLA were suspended in a $0.5 \% \mathrm{CMC}$ solution, while $\mathrm{APO}$ was dissolved in $0.9 \% \mathrm{NaCl}$ plus 2 drops of $0.1 \%$ ascorbic acid. Between the tests with different assays, there was a $24 \mathrm{~h}$ washout period to wash out the drug residues or its active metabolites. The controls were given $\mathrm{CMC}$ only $(2 \mathrm{~mL}$, ip or $0.9 \%$ $\mathrm{NaCl}$ plus 2 drops of $0.1 \%$ ascorbic acid sc) according to the same schedule. Separate groups of animals were used for different tests.

\section{Prenatal stress procedure (27)}

Beginning on day 14 of gestation, the pregnant dams were exposed to a repeated variable stress paradigm until the delivery of their pups on a gestational day 22 or 23 as previously described. The stress- 
es used in this paradigm included: (1) restraint in metal tube for $1 \mathrm{~h},(2)$ exposure to a cold environment $\left(4^{\circ} \mathrm{C}\right)$ for $6 \mathrm{~h},(3)$ overnight food deprivation, (4) $15 \mathrm{~min}$ of swim stress in water of ambient temperature, (5) lights on for $24 \mathrm{~h}$, and (6) social stressinduced by overcrowded housing conditions during the dark phase of the cycle. A typical schedule of the stress applications is presented in Table 1. Pregnant control dams remained in the animal room from gestational days 14-21 and were only exposed to normal animal room husbandry procedures. All dams delivered their pups vaginally.

\section{Behavioral analyses \\ Measurement of locomotor activity (LA)}

LA was measured in rats (NSCG and PSG group) using eight $20.5 \times 28 \times 21 \mathrm{~cm}$ wire grid cages, each with two horizontal infrared photocell beams along the long axis, $3 \mathrm{~cm}$ above the floor. Photocell interruptions were recorded by electromechanical counters in an adjacent room. Prior to the test, all groups of animals were habituated to a novel cage within a $30 \mathrm{~min}$ period. Subjects were tested on post-natal day 35 for single administration of CMC $30 \mathrm{~min}$ (ip) and $2.0 \mathrm{mg} / \mathrm{kg}$ APO $20 \mathrm{~min}$ ( $s c$ ) before LA in NSCG and PSG group. Rats were also treated with $1.5 \mathrm{mg} / \mathrm{kg}$ ARI (ip), $0.5 \mathrm{mg} / \mathrm{kg}$ OLA (ip) or saline in NSCG and PSG study groups. Photocell activity would subsequently be recorded at 10-min intervals for $1 \mathrm{~h}$. This test provided an index of basal locomotor activity of animals in a familiar environment, necessary to indicate the presence of a central stimulant or sedating effects of the drug used in the novelty test.

\section{Morris water maze test (MWM) (28)}

MWM apparatus was a circular basin (diameter $=180 \mathrm{~cm}$, height $=50 \mathrm{~cm}$ ) filled with water (approximately $22-24^{\circ} \mathrm{C}$ ) to a depth of $24 \mathrm{~cm}$, and pieces of Styrofoam were hiding an escape platform (diameter $=8 \mathrm{~cm}$ ) that was placed $1 \mathrm{~cm}$ below the water surface (learning place, invisible condition). Many extra-maze visual cues surrounding the maze were available, and the observer remained in the same location for each trial. The rats were placed in the water facing the midpoint section of the wall at one of 4 equally spaced locations: north (N), east (E), south (S) and west (W). The pool was divided into 4 quadrants: NW, NE, SE, and SW. The rats were allowed to swim freely until they found and climbed onto the platform. If a rat failed to locate the platform within $60 \mathrm{~s}$, it would be put on the platform for $5 \mathrm{~s}$. Each rat was submitted to 6 trials per day, and the starting position was changed at each trial (starting on the $\mathrm{N}$ side, followed by $\mathrm{E}, \mathrm{S}, \mathrm{W}$ sides, in that order). The interval was $5 \mathrm{~min}$ between trials 1-3 and 4-6 and 10 min between trials 3 and 4 . For the first 3 days of maze testing, the submerged platform was placed in the NW quadrant. The platform was subsequently placed in the SE quadrant for the following 2 days. After these 5 testing days, there was a period of 7 days without any testing. On day 6 , the rats were retested with the platform located in the same position as it had been on day 5 . On day 7 , the platform was lifted above the water level and placed in the SW quadrant, and rats were injected ARI $(1.5 \mathrm{mg} / \mathrm{kg})$ and OLA $(0.5$ $\mathrm{mg} / \mathrm{kg}$ ) $30 \mathrm{~min}$ before the test. Each rat was subjected to a one probe trial consisting of 6 individual

Table 1. Schedule of stress exposures applied in the prenatal stress paradigm (25).

\begin{tabular}{|c|c|c|c|}
\hline Gestation day & Morning & Midday & Evening \\
\hline 14 & $\begin{array}{l}\text { Metal tube } \\
60 \mathrm{~min}\end{array}$ & $\begin{array}{l}\text { Swim } \\
15 \mathrm{~min}\end{array}$ & $\begin{array}{l}\text { Metal tube } \\
60 \mathrm{~min}\end{array}$ \\
\hline 15 & \multicolumn{2}{|c|}{$\begin{array}{c}\text { Cold exposure } \\
6 \mathrm{~h}\end{array}$} & $\begin{array}{c}\text { Fast } \\
\text { overnight }\end{array}$ \\
\hline 16 & $\begin{array}{l}\text { Swim } \\
15 \mathrm{~min}\end{array}$ & $\begin{array}{l}\text { Metal tube } \\
60 \mathrm{~min}\end{array}$ & $\begin{array}{l}\text { Swim } \\
15 \mathrm{~min}\end{array}$ \\
\hline 17 & Open & $\begin{array}{l}\text { Swim } \\
15 \mathrm{~min}\end{array}$ & $\begin{array}{l}\text { Lights on } \\
\text { overnight }\end{array}$ \\
\hline 18 & \multicolumn{3}{|c|}{$\begin{array}{c}\text { Social stress } \\
12 \mathrm{~h} \\
\end{array}$} \\
\hline 19 & $\begin{array}{l}\text { Metal tube } \\
60 \mathrm{~min}\end{array}$ & $\begin{array}{l}\text { Swim } \\
15 \mathrm{~min}\end{array}$ & $\begin{array}{l}\text { Metal tube } \\
60 \mathrm{~min}\end{array}$ \\
\hline 20 & & & $\begin{array}{c}\text { Cold exposure } \\
6 \mathrm{~h}\end{array}$ \\
\hline 21 & $\begin{array}{l}\text { Swim } \\
15 \mathrm{~min}\end{array}$ & $\begin{array}{l}\text { Metal tube } \\
60 \mathrm{~min}\end{array}$ & $\begin{array}{l}\text { Swim } \\
15 \mathrm{~min}\end{array}$ \\
\hline
\end{tabular}


trials. The total number of times each rat crossed the probe (crossed quadrants - space navigation) target area and the time of the probe trial (escape latencies - space exploration) swim were recorded by the observer. The time of each of the 6 trials was noted, and the mean value for each rat was calculated. The same procedures were followed in chronic experiments.

After prolonged administration of ARI and OLA ( 7,14 and 21 days), the drug effects were tested as described for day 7 of the MWM test procedure.

\section{Statistical analysis}

The data are shown as mean values \pm SEM. The data distribution pattern was not normal (unlike Gaussian function). Statistical analyses for spatial memory test and LA test were carried out using the nonparametric Kruskal-Wallis test for unpaired data and ANOVA Friedman two-way analysis of variance test for paired data. Statistical significance was tested using Dunn's post-hoc test.

\section{RESULTS}

Effects of single administration of APO on locomotor activity in the NSCG and PSG female rat groups

APO applied in the dose of $2.0 \mathrm{mg} / \mathrm{kg} 20 \mathrm{~min}$ before the test (29) - (Table 2) increased the mobility of animals both in the NSCG and PSG. In the PSG, a statistically significant increase of mobility comparing to APO NSCG has been observed (which confirms a proper selection of the animal model of schizophrenia (AMS).

Effects of single and repeated administration of ARI and OLA on memory measured in the MWM test (number of escape latencies) in the NSCG and PSG female rat groups

In female rats that had been exposed to prenatal stress, a disturbed spatial memory was observed (an increase of escape latency in PSG rats comparing to NSCG group after 14 and 21 days of studying) (Table 3).

A single administration of ARI at the dose of $1.5 \mathrm{mg} / \mathrm{kg} 30 \mathrm{~min}$ before the test did not yield any memory improvement in NSCG and PSG. Nevertheless, after multiple administration of ARI (7, 14 and 21 days), an improvement of spatial memory in NSCG and PSG was observed (Table 3).

A single administration of OLA at the dose of $0.5 \mathrm{mg} / \mathrm{kg} 30 \mathrm{~min}$ before the test failed to improve memory in either NSCG or PSG. In NSCG, continuous administration of OLA improved memory after 7 days of medicine intake; no memory improvement was observed, however, after 14 and 21 days of OLA administration (Table 3). In PSG, spatial memory improvement was observed 7,14 and 21 days of OLA administration (Table 3).

In prenatally stressed females, no deterioration of spatial memory compared to NSCG was observed in terms of the number of quadrants crossed (Table 4).

Table 2. Effects of a single administration of APO on LA in the NSCG and PSG female rat groups.

\begin{tabular}{|c|c|}
\hline \multirow{3}{*}{ Group } & Activity counts / mean \\
\hline & Single treatment \\
\hline & Post-natal day $35(\mathrm{x} \pm \mathrm{SEM})$ \\
\hline \multicolumn{2}{|c|}{ NON-STRESSED CONTROL GROUP (NSCG) } \\
\hline $\mathrm{NaCl}(0.5 \mathrm{~mL} / \mathrm{rat}) \mathrm{CONTROL}$ & $72.0 \pm 8.6$ \\
\hline $\begin{array}{c}\text { APO2.0 } \mathrm{mg} / \mathrm{kg} \mathrm{sc} . \\
20 \mathrm{~min} \text { before } \\
\text { the test }\end{array}$ & $123.4 \pm 7.4^{*}$ \\
\hline \multicolumn{2}{|c|}{ PRENATALLY STRESSED GROUP (PSG) } \\
\hline $\mathrm{NaCl}(0.5 \mathrm{~mL} / \mathrm{rat}) \mathrm{CONTROL}$ & $104.2 \pm 14.8^{*}$ \\
\hline $\begin{array}{c}\text { APO } 2.0 \mathrm{mg} / \mathrm{kg} \mathrm{sc} . \\
20 \mathrm{~min} \text { before } \\
\text { the test }\end{array}$ & $156.5 \pm 15.1^{\text {o\# }}$ \\
\hline Kruskal-Wallis H & 16.2 \\
\hline
\end{tabular}

Number of housed animals $(n)=10 ; *$ Statistically significant difference $\mathrm{p}<0.05$ vs. NaCl group NSCG; ${ }^{\circ}$ Statistically significant difference $\mathrm{p}<0.05$ vs. $\mathrm{NaCl}$ group PSG; "Statistically significant difference $\mathrm{p}<0.05$ vs. APO group PSG 
Table 3. Effects of single and repeated administration of ARI and OLA on memory measured in MWM test (number of escape latencies) in the NSCG and PSG female rat groups.

\begin{tabular}{|c|c|c|c|c|c|}
\hline \multirow{3}{*}{ Group } & \multicolumn{4}{|c|}{ Escape latency [s] } & \multirow{3}{*}{$\begin{array}{r}\text { Friedman } \\
\mathrm{H}[3.37]\end{array}$} \\
\hline & \multirow{2}{*}{$\begin{array}{c}\text { Single } \\
\text { administration } \\
(\mathrm{x} \pm \mathrm{SEM})\end{array}$} & \multicolumn{3}{|c|}{ Chronic treatment } & \\
\hline & & $\begin{array}{c}7 \text { days } \\
(x \pm \text { SEM })\end{array}$ & $\begin{array}{c}14 \text { days } \\
(\mathrm{x} \pm \text { SEM })\end{array}$ & $\begin{array}{c}21 \text { days } \\
(\mathrm{x} \pm \mathrm{SEM})\end{array}$ & \\
\hline \multicolumn{6}{|c|}{ NON-STRESSED CONTROL GROUP (NSCG) } \\
\hline $\begin{array}{l}\text { CMC }(0.5 \mathrm{~mL} / \mathrm{rat}) \\
\text { CONTROL }\end{array}$ & $11.1 \pm 1.24$ & $10.3 \pm 1.0$ & $6.3 \pm 0.7$ & $5.9 \pm 0.6$ & 7.8 \\
\hline $\begin{array}{l}\text { ARI } 1.5 \mathrm{mg} / \mathrm{kg} \text { ip. } \\
30 \mathrm{~min} \text { before the test }\end{array}$ & $11.5 \pm 1.0$ & $6.2 \pm 0.9^{*}$ & $4.7 \pm 0.7^{*}$ & $4.3 \pm 0.5^{*}$ & 10.7 \\
\hline $\begin{array}{l}\text { OLA } 0.5 \mathrm{mg} / \mathrm{kg} \text { ip. } \\
30 \mathrm{~min} \text { before the test }\end{array}$ & $9.7 \pm 1.3$ & $5.7 \pm 0.7^{*}$ & 7.8. \pm 0.7 & $6.6 \pm 1.0$ & 5.0 \\
\hline \multicolumn{6}{|c|}{ PRENATALLY STRESSED GROUP (PSG) } \\
\hline $\begin{array}{l}\mathrm{CMC}(0.5 \mathrm{~mL} / \mathrm{rat}) \\
\text { CONTROL }\end{array}$ & $12.6 \pm 2.7$ & $10.9 \pm 1.1$ & $9.4 \pm 1.1^{*}$ & $8.7 \pm 0.81^{*}$ & 7.7 \\
\hline $\begin{array}{l}\text { ARI } 1.5 \mathrm{mg} / \mathrm{kg} \text { ip. } \\
30 \mathrm{~min} \text { before the test }\end{array}$ & $15.5 \pm 2.2$ & $7.2 \pm 0.9^{\circ}$ & $6.8 \pm 0.8^{\circ}$ & $5.6 \pm 0.8^{\circ}$ & 10.5 \\
\hline $\begin{array}{l}\text { OLA } 0.5 \mathrm{mg} / \mathrm{kg} \text { ip. } \\
30 \mathrm{~min} \text { before the test }\end{array}$ & $12.3 \pm 1.8$ & $6.2 \pm 0.8^{\circ}$ & $6.4 \pm 0.8^{\circ}$ & $6.7 \pm 0.7^{\circ}$ & 8.6 \\
\hline Kruskal-Wallis H [5.55] & 3.5 & 19.4 & 10.4 & 11.5 & \\
\hline
\end{tabular}

$\mathrm{n}=10 ; *^{*}$ Statistically significant difference $\mathrm{p}<0.05$ vs. CMC group NSCG; ${ }^{\circ}$ Statistically significant difference $\mathrm{p}<0.05$ vs. CMC group PSG

After a single administration of ARI at the dose of $1.5 \mathrm{mg} / \mathrm{kg} 30 \mathrm{~min}$ before the test, memory deterioration (increased number of quadrants crossed) was observed in PSG. After multiple administration of ARI (21 days), a spatial memory improvement in both NSCG and PSG was observed (Table 4). A single administration of OLA at the dose of $0.5 \mathrm{mg} / \mathrm{kg}$ $30 \mathrm{~min}$ before the test failed to improve memory in either NSCG or PSG. In NSCG, continuous administration of OLA improved the memory after 7 days while no memory improvement was noted in PSG after continuous administration of OLA (Table 4).

\section{DISCUSSION}

Studies show that the environment and psychosocial stress might be relevant factors in the development of schizophrenia (30). Prenatal exposure to strong stress frequently leads to changes in brain structure (31) and increases the risk of the disease (32). Stress could deteriorate cognitive functions, hence exacerbating schizophrenia symptoms (33, 34). It has been indicated that separating newborn offspring from their mother results in considerable stress and increases blood glycocorticosteroid level which can elicit schizophrenia symptoms in adult life (35).
In studies conducted on prenatally stressed female rats, increased locomotor activity has been observed compared to the activity after apomorphine administration (29). These results also correspond to an increased level of plasma corticosterone in rats (11). Similar results were noted by Koening et al. (36) which confirms a proper selection of the AMS applied.

Despite this fact, none of the known AMS completely reflects the clinical features of the disease, a model using prenatal stress generates an increase of LA level typical for schizophrenia, memory deterioration and a higher level of corticosterone (11).

An increase of locomotor activity in PSG rats may be connected with increased release of DA in the striatum and nucleus accumbens (NAc) (37). Our results are consistent with the study by Laruelle et al. (38), which found the increased DA release in the striatum to be strictly connected with increased locomotor activity in prenatally stressed rats. Similar results were obtained by McCormick et al. (39) in studies on female rats. Bowman et al. (40), however, failed to observe increased activity of animals in a study conducted on Sprague Dawley female rats. Nonetheless, female rats tended to be more anxious. 
The literature review emphasizes gender differences in predisposition to schizophrenia (41). It has been pointed out that the incidence of schizophrenia is higher among men than women. Some studies also show gender differences regarding the pharmacotherapy applied $(42,43)$.

The terapeutic efficacy of drugs depends on pharmacokinetic parameters which in turn depend on the drug dose used, age, and gender (44). Detailed gender-related differences are observed in women in terms of absorption phased in LADME due to the higher $\mathrm{pH}$ level compared to men (44, 45). This leads to Cmax reduction (45) and attenuation of the first-pass effect in connection with CYP2D6 cytochrome induction (24). Other major gender-related pharmacokinetic parameters include binding to proteins, and distribution and metabolism phases depending on the effect of estrogen and progesterone (46). According to the results presented by Su-Young Choi et al. (47) estradiol may affect the activity of CYP2A6, CYP2B6, and CYP3A4 cytochromes, while progesterone may modify the expression of CYP2A6, CYP2B6, CYP2C8, CYP3A5 cytochromes. For our studies, CYP3A4 cytochrome is of particular importance as it is involved in ARI's and OLA's metabolism. As shown by the results obtained by Hagg (48), there are also significant differences in the metabolism of CYP2D6 cytochrome. The authors pointed out that the expression of this cytochrome in women was $16 \%$ lower than in men. Other studies confirm this fact as well $(49,50)$. Another major gender-related parameter is the lipid compartment which extends the drug's half-life $\left(\mathrm{T}_{1 / 2}\right)$ in women (46).

Prenatally stressed rats had greater difficulties in performing simple activities - searching for the footway in spatial memory test according to MWM (51) - which was confirmed by our earlier studies $(11,26)$. Similar results confirm that chronic exposure to stress disturbs memory functions in animals regardless of their gender. Corresponding results were obtained by Saju et al. (52), who confirmed that chronic stress results in considerable changes in the hippocampus - lower number of neurons - in prenatally stressed female offspring.

Chronic administration of ARI ( 7 to 21 days) resulted in spatial memory improvement in the NSCG. This corroborates with the results of Burda et al. (53) which showed a higher dose of ARI (6 $\mathrm{mg} / \mathrm{kg}$ ) to have improved cognitive functions. In contrast, studies by Ratajczak $(11,54)$ confirmed the improvement of spatial memory in male rats after multiple administration of ARI at the dose of 1.5 $\mathrm{mg} / \mathrm{kg}$. The memory improvement mechanism is

Table 4. Effects of single and repeated administration of ARI and OLA on memory measured in MWM test (number of quadrants crossed) in the NSCG and PSG female rat groups.

\begin{tabular}{|c|c|c|c|c|c|}
\hline \multirow{3}{*}{ Group } & \multicolumn{4}{|c|}{ Quadrants crossed } & \multirow{3}{*}{$\begin{array}{c}\text { Friedman } \\
\mathrm{H}[3.37]\end{array}$} \\
\hline & \multirow{2}{*}{$\begin{array}{c}\text { Single } \\
\text { administration } \\
(\mathrm{x} \pm \mathrm{SEM})\end{array}$} & \multicolumn{3}{|c|}{ Chronic treatment } & \\
\hline & & $\begin{array}{c}7 \text { days } \\
(\mathrm{x} \pm \text { SEM })\end{array}$ & $\begin{array}{c}14 \text { days } \\
(\mathrm{x} \pm \text { SEM })\end{array}$ & $\begin{array}{c}21 \text { days } \\
(\mathrm{x} \pm \text { SEM })\end{array}$ & \\
\hline \multicolumn{6}{|c|}{ NON-STRESSED CONTROL GROUP (NSCG) } \\
\hline $\begin{array}{c}\mathrm{CMC}(0.5 \mathrm{~mL} / \mathrm{rat}) \\
\text { CONTROL }\end{array}$ & $3.3 \pm 0.5$ & $2.3 \pm 0.3$ & $2.2 \pm 0.2$ & $1.6 \pm 0.3$ & 3.5 \\
\hline $\begin{array}{l}\text { ARI } 1.5 \mathrm{mg} / \mathrm{kg} \text { ip. } \\
30 \mathrm{~min} \text { before the test }\end{array}$ & $4.2 \pm 0.3$ & $1.6 \pm 0.2$ & $1.7 \pm 0.3$ & $0.8 \pm 0.2 *$ & 7.7 \\
\hline $\begin{array}{l}\text { OLA } 0.5 \mathrm{mg} / \mathrm{kg} \text { ip. } \\
30 \mathrm{~min} \text { before the test }\end{array}$ & $3.1 \pm 0.4$ & $0.8 \pm 0.2 *$ & $1.8 \pm 0.3$ & $1.1 \pm 0.2$ & 8.1 \\
\hline \multicolumn{6}{|c|}{ PRENATALLY STRESSED GROUP (PSG) } \\
\hline $\begin{array}{c}\mathrm{CMC}(0.5 \mathrm{~mL} / \mathrm{rat}) \\
\text { CONTROL }\end{array}$ & $4.0 \pm 0.7$ & $2.4 \pm 0.3$ & $2.3 \pm 0.4$ & $1.7 \pm 0.3$ & 1.3 \\
\hline $\begin{array}{l}\text { ARI } 1.5 \mathrm{mg} / \mathrm{kg} \text { ip. } \\
30 \mathrm{~min} \text { before the test }\end{array}$ & $6.7 \pm 0.7 \mathrm{o}$ & $3.3 \pm 0.6$ & $2.7 \pm 0.4$ & $1.5 \pm 0.2$ & 6.7 \\
\hline $\begin{array}{l}\text { OLA } 0.5 \mathrm{mg} / \mathrm{kg} \text { ip. } \\
30 \mathrm{~min} \text { before the test }\end{array}$ & $4.7 \pm 0.7$ & $2.8 \pm 0.5$ & $2.4 \pm 0.3$ & $2.3 \pm 0.3$ & 6.1 \\
\hline Kruskal-Wallis H [5.55] & 10.2 & 11.7 & 3.5 & 9.1 & \\
\hline
\end{tabular}

$\mathrm{n}=10 ; *$ Statistically significant difference $\mathrm{p}<0.05$ vs. CMC group NSCG; ${ }^{\circ}$ Statistically significant difference $\mathrm{p}<0.05$ vs. CMC group PSG 
generated by the effect of ARI on DA receptors located in the prefrontal cortex (PFC) (55), as well as the inhibition of $\mathrm{D} 2$ receptor activity in the mesolimbic system and activation of this activity in the prefrontal cortex (53). Similar results were obtained by Li et al. (56) who observed a reduced DA release in NAc and explained it as the agonistic effect of ARI on D2/D3 receptors. They also noted that ARI at the dose of $1 \mathrm{mg} / \mathrm{kg}$ had an antagonistic effect on D2 receptors and agonistic effect on 5HT1A receptor. No gender-related differences in plasma concentration have been found for ARI (57-59). This does not change the fact that potential differences in terms of metabolism using equivalent isoforms of P-450 cytochrome might be important in this drug's case. This may partially explain the results obtained by the researchers in our study.

Spatial memory improvement in PSG female rats was observed after multiple administration of ARI (7, 14 and 21 days). Corresponding results were obtained in our previous studies (on males) $(11,53)$, also confirmed by other authors $(60,61)$. This suggests that DA receptors located in the dorsal-lateral region of the PFC, in particular, are responsible for memory improvement in prenatally stressed rats (of both sexes). This effect may also depend on the dose of ARI used during the study since Enomoto et al. (62) claimed that ARI administered in lower doses $(0.3$ and $1 \mathrm{mg} / \mathrm{kg})$ did not improve spatial memory in MWM.

In the case of OLA administered to the NSCG, only temporary improvement of memory was observed (after 7 days of treatment). Nonetheless, in the case of PSG rats, OLA improved memory after 7,14 , and 21 days of treatment. These results are consistent with the studies by Levin et al. (63) (46), who also observed a memory improvement in adult female Sprague-Dawley rats in 8-arm radial in doses of OLA between 31.25 and $250 \mu \mathrm{g} / \mathrm{kg}$ in females. There are no studies devoted to OLA's effect on prenatally stressed females.

In the study on the administration of OLA to non-stressed male rats, Ratajczak et. al. (11) observed that spatial memory improved after chronic treatment (14-21 days). Similar results were obtained by Nowakowska et al. (64) who confirmed that OLA improved spatial memory in male rats after multiple administration of the drug. The improvement of cognitive functions may be related to the antagonistic effect of OLA on 5-HT2A, 5HT2C, 5-HT6 receptors and the activation of 5HT1A receptors (65). Nevertheless, the effect of memory improvement in stressed male rats was observed after both single and multiple administration of OLA (11). Other authors failed to find this dependence in the MWM test $(66,67)$. The lack of such effect in prenatally stressed animals can be explained by the blockade of D2 and 5-HT2A receptors during OLA administration (both single and repeated), with concurrent OLA stimulation of DA receptors type D1 and D3. According to the study by Callaghan et al. (68) gender is of fundamental importance for OLA's pharmacokinetics, particularly for the metabolism of P-450 cytochrome, by leading to plasma concentration increase in women (57).

Differences in behavioral effects in female and male rats can be explained by enzymatic differences related to functions of digestive systems between males and females, hormonal differences among females. It may also be of paramount importance in the occurrence of memory disorders in schizophrenia (the different activity of testosterone and estrogen) (69) Such differences may also affect the drug's therapeutic efficacy due to the drug's interaction with the hormonal system which - in OLA's case - may lead to memory improvement in women also observed following treatment with fluoxetine (26).

\section{CONCLUSION}

In female rats, prenatal stress causes spatial memory disorders that are typical for the course of schizophrenia. Chronic administration of ARI and OLA inverts this effect in the case of females exposed to prenatal stress. This effect may probably be related to ARI's mechanism of action (agonist or antagonist), mainly on D2 and 5-HT2A receptors, and OLA's antagonistic effect on these receptors in relation to memory. These results may suggest that chronic drug administration is required to achieve the effect of memory improvement in females. Moreover, both male hormones (androgens) and female hormones (estrogens) may modify both axonal and receptor connections in the brain and the succession of changes in psychobehavioral terms which might lead to the modified efficacy of the pharmacotherapy applied.

\section{Conflict of interest}

The authors declare no conflicts of interest.

\section{REFERENCES}

1. Rado J., Janicak P.G.: Clin. Interv. Aging. 5, 253 (2010).

2. Zaprutko T., Kopciuch D., Sawicka D., Majchrzycka B., Nowak M. et al.: Acta Pol. Pharm. 75, 813 (2018). 
3. Rybakowski J., Rybakowski F.: Psychiatria Sedno, Elsevier, Urban \& Partner. Tom 1-2 (2008) (in Polish).

4. Zaprutko T., Göder R., Kus K., Rakhman L., Bilobryvka R., Nowakowska E.: Psychiatr. Q. 87, 595 (2016).

5. Holzman P.S.: Neuropsychopharmacology 25, 299 (2001).

6. Moffitt T.E.: Psychol. Bull. 131, 533 (2005).

7. Castle D.J., Buckley P.F.: Schizophrenia. Oxford University Press, 128 (2015).

8. Bilikiewicz A., Pużyński S., Rybakowski J., Wciórka J.: Psychiatria - podstawy psychiatrii, Elsevier Urban \& Partner (2002) (in Polish).

9. Rykaczewska-Czerwińska M., Oleś P., Oleś M., Kuczer M., Konopińska D., Plech A.: Acta Pol. Pharm. 72, 205 (2015)

10. Ratajczak P., Wozniak A., Nowakowska E.: Acta Neurobiol. Exp. (Wars) 73, 472 (2013).

11. Ratajczak P., Kus K., Jarmuszkiewicz Z., Woźniak A., Cichocki M., Nowakowska E.: Pharmacol. Rep. 65, 30 (2013).

12. Cerqueira J.J., Pego J.M., Taipa R., Bessa J.M., Almeida OFX., Sousa N.: J. Neurosci. 25, 7792 (2005).

13. Ratajczak P., Kus K., Skurzyńska M., Nowakowska E.: Hum. Exp. Toxicol. 37, 972 (2018).

14. Ratajczak P., Nowakowska E., Kus K., Danielewicz R., Herman S., Woźniak A.: Hum. Exp. Toxicol. 34, 526 (2015).

15. Swainston H.T., Perry C.M.: Drugs 64, 1715 (2004)

16. Lawler C.P., Prioleau C., Lewis MM., Mak C., Jiang D., Schetz JA.: Neuropsychopharmacology 20, 612 (1999).

17. Mailman R.B., Murthy V.: Curr. Pharm. Des. 16, 488 (2010).

18. Padín J.F., Rodríguez M.A., Domínguez E., Dopeso-Reyes I.G., Buceta M., Cano E.: Neuropharmacology 51, 923 (2006).

19. Naiker D.V., Catts S.V., Catts V.S., Bedi K.S., Bryan-Lluka L.J.: Eur. J. Pharmacol. 540, 87 (2006).

20. Pereira A., Zhang B., Malcolm P., SugihartoWinarno A., Sundram S.: BMC Neurosci. 15, 30 (2014).

21. Koren G.: J. Popul. Ther. Clin. Pharmacol. 20, e358 (2013).

22. Women and Psychopharmacology http://www. medscape.com/viewarticle/423938 [accessed on 18. 02. 2019].

23. Wilson K.: Clin. Pharmacokinet. 9, 189 (1984).

24. Luzier A.B., Killian A., Wilton J.H., Wilson M.F., Forrest A., Kazierad D.J.: Clin. Pharmacol. Ther. 66, 594 (1999).
25. Meibohm B., Beierle I., Derendorf H.: Clin. Pharmacokinet. 41, 329 (2002).

26. Kus K., Ratajczak P., Czaja N., Zaprutko T., Nowakowska E.: Acta Neurobiol. Exp. (Wars) 77, 86 (2017).

27. Kinnunen A.K., Koenig J.I., Bilbe G.: J. Neurochem. 86, 736 (2003).

28. Morris R.: J. Neurosci. Methods. 11, 47 (1984).

29. Braga P.Q., Dias F.R., Carey R.J., Carrera M.P.: Pharmacol. Biochem. Behav. 93, 128 (2009).

30. Betensky J.D., Robinson D.G., Gunduz-Bruce H., Sevy S., Lencz T., Kane JM: Psychiatry Res. 160, 38 (2008).

31. Charmandari E., Kino T., Souvatzoglou E., Chrousos GP.: Horm. Res. 59, 161 (2003).

32. Corcoran C., Gallitano A., Leitman D., Malaspina D.: J. Psychiatr. Pract. 7, 3 (2001).

33. Norman R.M., Malla A.K.: Soc. Psychiatry Psychiatr. Epidemiol. 29, 244 (1994).

34. Dziwota E., Olajossy M.: Acta Pol. Pharm. 73, 1433 (2016).

35. Smotherman W.P., Robinson S.R., La Vallee P.A., Hennessy M.B.: Dev. Psychobiol. 20, 415 (1987).

36. Koenig J.I., Kirkpatrick B., Lee P.: Neuropsychopharmacology 27, 309 (2002).

37. Gulley J.M., Kuwajima M., Mayhill E., Rebec G.V.: Brain Res. 845, 68 (1999).

38. Laruelle M., Abi-Dargham A., van Dyck C.H., Gil R., D'Souza C.D. et al.: Proc. Natl. Acad. Sci. USA. 93, 9235 (1996).

39. McCormick C.M., Merrick A., Secen J., Helmreich D.L.: J. Neuroendocrinol. 19, 116 (2007).

40. Bowman R.E., Kelly R.: Stress 15, 524 (2012).

41. Leung A., Chue P.: Suppl. 401, 3 (2000).

42. Seeman M.V.: Acta Psychiatr. Scand. 125, 363 (2000).

43. Kulkarni J., Hayes E., Gavrilidis E.: Curr. Opin. Psychiatry 25, 89 (2012).

44. Beierle I., Meibohm B., Derendorf H.: Int. J. Clin. Pharmacol. Ther. 37, 529 (1999).

45. Robinson G.E.: Medscape Women's Health eJour 7, 1 (2002).

46. Aichhorn W., Whitworth A.B., Weiss E.M., Marksteiner J.: Drug Saf. 29, 587 (2006).

47. Choi S.Y., Koh K.H., Jeong H.: Drug Metab. Dispos. 41, 263 (2013).

48. Hägg S., Spigset O., Dahlqvist R.: Br. J. Clin. Pharmacol. 51, 169 (2001).

49. Llerena A., Cobaleda J., Martínez C., Benítez J.: Eur. J. Drug Metab. Pharmacokinet. 21, 129 (1996). 
50. Tamminga W.J., Wemer J., Oosterhuis B., Weiling J., Wilffert B. et al.: Eur. J. Clin. Pharmacol. 55, 177 (1999).

51. Leucht S., Corves C., Arbter D., Engel R.R., Li C., Davis J.M.: Lancet 373, 31 (2009).

52. Cherian S.B., Bairy K.L., Rao M.S.: Indian. J. Exp. Biol. 47, 893 (2009).

53. Burda K., Czubak A., Kus K., Nowakowska E., Ratajczak P., Zin J.: Pharmacol. Rep. 63, 898 (2011).

54. Ratajczak P., Kus K., Jarmuszkiewicz Z., Woźniak A., Nowakowska E.: Arzneimittelforschung 62, 614 (2012).

55. Díaz-Mataix L., Scorza M.C., Bortolozzi A., Toth M., Celada P., Artigas F.: J. Neurosci. 25, 10831 (2005).

56. Li Z., Ichikawa J., Dai J., Meltzer HY.: Eur. J. Pharmacol. 493, 75 (2004).

57. Weiss U., Marksteiner J., Kemmler G., Saria A., Aichhorn W.: J. Clin. Psychopharmacol. 25, 570 (2005).

58. Anthony M., Berg M.J.: J. Womens Health Gend. Based Med. 11, 617 (2002).

59. Wilner K.D., Demattos S.B., Anziano R.J., Apseloff G., Gerber N.: Br. J. Clin. Pharmacol. 49, 43S (2000).
60. Conroy S.K., Rodd Z., Chambers R.A.: Pharmacol. Biochem. Behav. 86, 386 (2007).

61. Kleven M.S., Barret-Grévoz C., Bruins Slot L., Newman-Tancredi A.: Neuropharmacology 49, 135 (2005).

62. Enomoto T., Ishibashi T., Tokuda K., Ishiyama T., Toma S., Ito A.: Behav. Brain Res. 186, 197 (2008).

63. Levin ED., Petro A., Beatty A.: Neurotoxicol. Teratol. 27, 459 (2005).

64. Nowakowska E., Kus K., Polański A., Burda K., Nowakowska A., Sadowski C.: Pharmacol. Rep. 63, 372 (2011).

65. Woodward N.D., Purdon S.E., Meltzer H.Y., Zald D.H.: Int. J. Neuropsychopharmacology 8, 457 (2005).

66. Markham J.A., Taylor A.R., Taylor S.B., Bell D.B., Koenig J.I.: Front. Behav. Neurosci. 4, 173 (2010).

67. Lemaire V., Koehl M., Le Moal M., Abrous D.N.: Proc. Natl. Acad. Sci. USA 97, 11032 (2000).

68. Callaghan J.T., Bergstrom R.F., Ptak L.R., Beasley C.M.: Clin. Pharmacokinet. 37, 177 (1999).

69. Stevens JR.: Am. J. Psychiatry 159, 713 (2002).

Received: 20.03.2019 